\title{
Tocolysis among Women with Preterm Birth: Associated Factors and Outcomes from a Multicenter Study in Brazil
}

\section{Tocólise com parto prematuro: fatores associados e desfechos de um estudo multicêntrico no Brasil}

\author{
Tabata Zumpano Dias ${ }^{1}$ Mariana Lacerda Fava ${ }^{1}$ Renato Passini Júnior ${ }^{1} \quad$ Jose Guilherme Cecatti ${ }^{1}$ \\ Ricardo Porto Tedesco ${ }^{2}$ Giuliane Jesus Lajos ${ }^{1}$ Patricia Moretti Rehder ${ }^{1}$ Marcelo Luis Nomura ${ }^{1}$ \\ Paulo Fanti Oliveira ${ }^{3}$ Maria Laura Costa ${ }^{1}$
}

1 Department of Obstetrics and Gynecology, School of Medical

Sciences, Universidade Estadual de Campinas, Campinas, SP, Brazil

Address for correspondence Tabata Zumpano Dias, PhD, Universidade Estadual de Campinas (UNICAMP), Cidade Universitária

2 Department of Obstetrics and Gynecology, Faculdade de Medicina Zeferino Vaz, 13083-970, Barão Geraldo, Campinas, SP, Brazil

de Jundiaí, Jundiaí, SP, Brazil

3 Unit of Statistics, School of Medical Sciences, Universidade Estadual (e-mail: tabatazumpano@gmail.com).

de Campinas, Campinas, SP, Brazil

Rev Bras Ginecol Obstet 2018;40:171-179.

\begin{abstract}
Keywords

- preterm birth

- prematurity

- preterm labor

- tocolysis

- neonatal outcomes

- maternal outcomes

Objective To evaluate the use of tocolysis in cases of preterm birth due to spontaneous preterm labor in a Brazilian sample.

Methods A sample of 1,491 women with preterm birth due to spontaneous preterm labor were assessed, considering treatment with tocolysis or expectant management, according to gestational age at birth ( $<34$ weeks and 34 to $36+6$ weeks) and drugs prescribed. The study took place in 20 Brazilian hospitals from April 2011 to July 2012. Bivariate analyses were conducted to evaluate associations with sociodemographic and obstetric characteristics and odds ratios with their respective $95 \%$ confidence intervals were estimated for maternal and neonatal outcomes.

Results A total of 1,491 cases of preterm birth were considered. Tocolysis was performed in 342 cases (23\%), 233 of which (68.1\%) were delivered before 34 weeks. Within the expectant management group, $73 \%$ was late preterm and with more advanced labor at the time of admission. The most used drugs were calcium channel blockers (62.3\%), followed by betamimetics (33\%). Among the subjects in the tocolysis group, there were more neonatal and maternal complications (majority non-severe) and an occurrence of corticosteroid use that was 29 higher than in the expectant management group.

Conclusion Tocolysis is favored in cases of earlier labor and also among those with less than 34 weeks of gestation, using preferably calcium channel blockers, with success in achieving increased corticosteroid use. Tocolysis, in general, was related to higher maternal and neonatal complication rates, which may be due to the baseline difference between cases at admission. However, these results should raise awareness to tocolysis use.
\end{abstract}

received

October 4, 2017

accepted

January 24, 2018
DOI https://doi.org/

10.1055/s-0038-1642025. ISSN 0100-7203.
Copyright (e 2018 by Thieme Revinter

Publicações Ltda, Rio de Janeiro, Brazil
License terms

(요 (1) $\Theta \circledast$ 


\begin{abstract}
Resumo

\section{Palavras-chave}

- parto prematuro

- prematuridade

- trabalho de parto prematuro

- tocólise

- desfechos neonatais

- desfechos maternos

Objetivo: Avaliar o uso da tocólise em partos prematuros decorrentes de trabalho de parto espontâneo numa amostra brasileira.

Métodos Um total de 1.491 mulheres com parto prematuro decorrente de trabalho de parto espontâneo foram avaliadas, considerando a realização de tocólise ou conduta expectante, de acordo com a idade gestacional ao nascimento ( $<34$ semanas e 34 a $36+6$ semanas) e com as drogas prescritas. O estudo ocorreu em 20 hospitais brasileiros, de abril de 2011a julho de 2012. Análises bivariadas foram realizadas para avaliar associações com características sociodemográficas e obstétricas. Foram calculadas as relações de probabilidade com seus respectivos intervalos de confiança (95\%) para os desfechos neonatais e maternos.

Resultados Um total de 1.491 casos de partos prematuros foram considerados, e a tocólise foi realizada em $342(23 \%)$ casos, dos quais $233(68,1 \%)$ tiveram partos antes das 34 semanas. No grupo da conduta expectante, $73 \%$ foram pré-termos tardios e com trabalho de parto mais avançado à admissão. As drogas mais utilizadas foram os bloqueadores do canal de cálcio (62.3\%), seguidos pelos betamiméticos (33\%). No grupo da tocólise houve mais complicações neonatais e maternas (maioria não grave) e um uso de corticosteroides 29 vezes mais frequente que nos casos de conduta expectante.

Conclusão A tocólise foi mais favorável nos casos de trabalho de parto inicial e nos partos realizados antes de 34 semanas de gestação, usando preferencialmente bloqueadores do canal de cálcio, com sucesso em realizar altas taxas de corticoterapia. A tocólise esteve associada a maiores taxas de complicações maternas e neonatais, o que pode ser explicado pela diferença basal dos casos à admissão. Entretanto, esses resultados devem acender um alerta em relação ao uso de tocolíticos.
\end{abstract}

\section{Introduction}

Despite recognized advances in obstetrical care in the last decades, preterm birth (PTB), defined as delivery before 37 weeks, continues to be one of the most significant burdens worldwide, with increasing numbers in most high and middle-income countries, including Brazil. ${ }^{1-3}$ Preterm newborns represented $\sim 10 \%$ of live births in Brazil in the last decade. ${ }^{4}$ The impact of prematurity is relevant not only for neonatal health but also for infant health, with major longterm consequences, such as neurologic handicap, deafness, blindness and chronic respiratory disease. ${ }^{5}$ Furthermore, prematurity is the main cause of neonatal deaths. ${ }^{6}$ Around $75 \%$ of PTBs follow spontaneous prematurity (preterm labor [PTL] and preterm premature rupture of membranes), while the remaining $25 \%$ are provider-initiated PTBs due to fetal or maternal complications. ${ }^{7,8}$

The pathogenesis of spontaneous PTBs is most likely multifactorial, which makes it very difficult to prevent or predict this condition. The main identified causes are related to intrauterine infection, bleeding and uterine overdistension, among others. ${ }^{3}$

Tocolysis is an available resource in the care of these women, aiming to prolong pregnancies. ${ }^{9}$ The use of tocolytic medications is not clearly associated with a reduction in perinatal or neonatal mortality; however, the potential benefits are related to inhibition of uterine contractions, allowing the administration of antenatal glucocorticoids. ${ }^{10}$ The antenatal corticosteroid administration is shown to reduce the risk of fetal complications related to prematurity, such as respiratory distress syndrome, intraventricular hemorrhage, and necrotizing enterocolitis. Another relevant goal of tocolysis is to allow the maternal transfer, in a timely manner, to a center with neonatal intensive care unit. 9,11

Tocolytic drugs should be considered only in the absence of contraindications, such as non-reassuring fetal status, severe fetal growth restriction, intra-amniotic infection, lethal fetal anomalies, and complicated maternal comorbidity. There are many groups of tocolytic drugs, and the decision as to which agent should be used for an individual woman should be based on multiple factors, including gestational age, medical conditions, cost, personal experience, and commercial availability. ${ }^{12}$

Calcium channel blockers (CCB), such as nifedipine, cause the inhibition of calcium reuptake by myometrial cell, leading to smooth muscle relaxation. Nifedipine is usually well tolerated and the main described mild side effects are nausea, flushing, headache, and palpitations. However rare, more severe side effects can also present, such as pulmonary edema, atrial fibrillation, and hypotension. The fetal side effects are related to maternal hypotension and placental 
hypoperfusion. A significant reduction in neonatal morbidity is shown with CCB use in comparison with other tocolytic drugs. ${ }^{13}$

Betamimetics (terbutaline) are $\beta$-adrenergic agonists that stimulate the enzyme adenyl cyclase in the smooth muscle cell. By doing so, they decrease the availability of intracellular calcium and suppress myometrial contractility. The most common maternal side effects are tachycardia, pulmonary edema, and hyperglycemia. For that reason, the woman should be constantly monitored. Furthermore, this class of medication is contraindicated in women with poorly controlled baseline diseases, such as diabetes or heart disease, and it should be discontinued if maternal heart rate reaches over 120 beats/minute or if the woman experiences chest pain or dyspnea. Terbutaline can cause fetal side effects, especially hypoglycemia and tachycardia. The use of betamimetics presented no benefits in comparison with placebo in cases of respiratory distress syndrome as well as in cases that resulted in perinatal or neonatal deaths. ${ }^{14}$

Prostaglandin inhibitors, such as indomethacin, constrain the cyclooxygenase enzyme, which synthesizes prostaglandins from arachidonic acid. The most common side effects are nausea, vomiting, gastritis, and platelet dysfunction. Indomethacin is contraindicated over 32 weeks of gestation because of the risk of premature closure of ductus arteriosus and oligohydramnios. No clear benefits were shown over placebo or any other tocolytics; however, a 2012 systematic review concluded that prostaglandin inhibitors and CCB had the highest probability of delaying delivery and improving neonatal and maternal outcomes. ${ }^{9,15}$

Oxytocin receptor antagonists (ORA), represented by atosiban, act on the uterine myometrial cell and can cause fewer side effects (like nausea, vomiting, and headache) than treatment with the CCB or betamimetics. Oxytocin receptor antagonists did not demonstrate superiority as a tocolytic compared with placebo, betamimetics or CCB for pregnancy prolongation or neonatal outcomes. ${ }^{16}$ Currently, this medication is not easily available in public hospitals in Brazil due to its high cost.

Magnesium sulfate reduces calcium in the intracellular and extracellular levels, which decreases myometrial contractility. The administration should be monitored regularly due to the risk of lethargy, nausea, hyporeflexia and respiratory depression. A Cochrane systematic review (2002) ${ }^{17}$ concluded that magnesium sulfate is ineffective at delaying birth and its use is associated with an increased mortality for the infant.

The long-term use of tocolysis has not shown effectiveness; therefore, tocolytics should not be continued once uterine contractions have been suppressed. ${ }^{13}$ The benefit of using associations of tocolytics are also not clear in the literature. ${ }^{18}$

Given the scarce data on the actual clinical practice on tocolysis in our setting, and the great variances among available protocols, this study aims to evaluate women with PTB due to PTL in 20 institutions of different regions of Brazil, regarding the prevalence of tocolytic drugs used, factors associated with this use, the most prescribed drugs, and the maternal and perinatal outcomes, according to the drug and gestational age considered.

\section{Methods}

This is a cross-sectional multicenter study called Brazilian Multicenter Study on Preterm Birth (Estudo Multicêntrico de Investigação de Prematuridade [EMIP, in the Portuguese acronym]), which assessed PTB in 20 obstetric reference hospitals in three regions of Brazil from April 2011 to July 2012. The research protocol and main results have already been published previously elsewhere. ${ }^{7,19}$

For the current analysis, we focused on cases of PTB (gestational age at birth up to $36+6$ weeks) due to PTL only. Among those, we analyzed the frequency of tocolysis and split all cases into two groups: women who underwent tocolysis, and those in which tocolysis was not performed (expectant group). Specific analyses were performed also considering only births before 34 weeks. Afterwards, a bivariate analysis was conducted to estimate the odds ratios (ORs) with their respective 95\% confidence intervals (CIs) for perinatal results. Finally, a comparison of maternal complications and neonatal outcomes between the two most prevalent classes of tocolytics, CCB and betamimetics, was considered. For statistical analysis, the Statistical Analysis System (SAS) for Windows version 9.4 (SAS Institute, Cary, NC, USA) was used. The Mann-Whitney test was performed to compare the numeric variables, and the Chi-square and Fisher Exact tests were used to evaluate the categorical variables.

This study followed all ethical principles of the Helsinki Declaration. It abides by the guidelines and rules of the Resolution 196/96 of the National Health Council on research involving human beings, current at the time of data collection. The study was approved by the National Council for Ethics in Research and by the Institutional Review Board of each participating institution. An Informed Consent Form was developed, and each subject was enrolled in the study only after the understanding and accepting the conditions on the form. Confidentiality of the data and medical care of these women were assured.

\section{Results}

From April 2011 to July 2012, 1,491 women with PTBs due to PTL were enrolled. Tocolysis was performed in 342 women, $23 \%$ of all PTBs. Out of these, 233 (68.1\%) delivered before 34 weeks, and 109 (31.9\%) delivered between 34 and $36+6$ weeks. Among women with expectant management, the majority was late preterm (73\%), as shown in - Fig. 1.

- Tables 1 and $\mathbf{2}$ present the sociodemographic characteristics, obstetric history and characteristics of the current pregnancy in the studied population. Among the women who underwent tocolysis, there were significantly more nulliparous, more cases with a history of vaginal bleeding during pregnancy, cervical insufficiency, women without comorbidities, the integrity of membrane at admission, more cases of antenatal corticosteroids prescribed and 


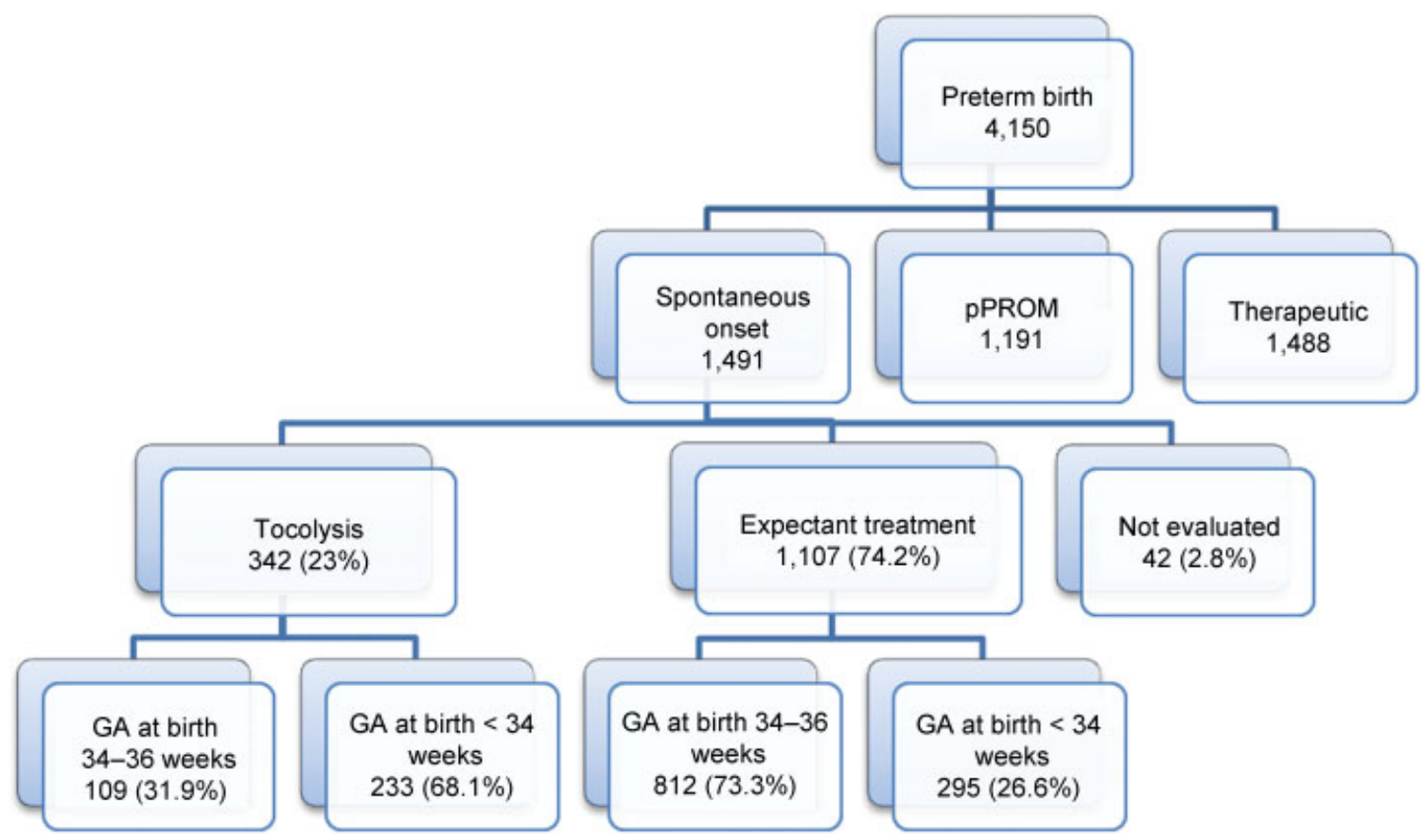

Fig. 1 Flowchart of subjects and gestational age at birth in the Brazilian Multicenter Study on Preterm Birth (EMIP, in the Portuguese acronym). Abbreviation: GA, gestational age.

more maternal complications. They were: 23 cases of genital hemorrhage (1.6\%), 57 chorioamnionitis $(3.9 \%)$, only one maternal sepsis $(0.1 \%), 6$ cases of treatment interruption due to adverse effects, only 1 cardiac decompensation ( $0.1 \%)$, 14 oligoamnios (1.0\%), 34 other complications (2.3\%) and 10 associations of answers ( $0.6 \%)$. The majority of cases related no maternal complications (1,292 or $88.3 \%$ ).

The cases of expectant management were clearly of more advanced labor at admission (significantly more contractions in 10 minutes and increased cervical dilation); the mean dilation at admission for expectant management was overall $5.3 \mathrm{~cm}$ and $6.5 \mathrm{~cm}$ under 34 weeks of gestation. Furthermore, cases submitted to tocolysis were more preterm (mean gestational age at birth of $\sim 31$ weeks versus 33 weeks for expectant management) and more likely to have neonatal intensive care unit (NICU) admission (-Table 2).

The most used class of tocolytic drug was the CCB (62.3\%), followed by betamimetics (33\%) and prostaglandin inhibitors (1.5\%) (-Fig. 2). There was a therapeutic failure in $11.3 \%$ of the attempted inhibitions, leading to change in the medication. Again, we considered only cases that progressed to PTB.

- Table 3 compares betamimetics and CCB concerning neonatal and maternal outcomes. The Cesarean section rate as well as the need for newborn admission to NICU were significantly higher in women who used betamimetics compared with those who used CCB.

Considering the clinically most relevant group for tocolysis, cases under 34 weeks of gestational age and comparing those submitted to tocolysis to those with expectant management, again it is clear that the cases of expectant management had more advanced labor at admission
Table 1 Comparison of sociodemographic characteristics, obstetric history, and current pregnancy conditions between women who were treated with tocolytic drugs and women who were treated expectantly (Chi-square test) $(n=1,449)$

\begin{tabular}{|c|c|c|c|}
\hline \multirow[t]{2}{*}{ Condition } & Tocolysis & Expectant & \multirow[t]{2}{*}{$p$ Value } \\
\hline & n (\%) & n (\%) & \\
\hline \multicolumn{4}{|l|}{ Maternal Age } \\
\hline$\leq 19$ & $114(33.3)$ & $313(28.2)$ & \\
\hline $20-34$ & $203(59.3)$ & $689(62.2)$ & 0.1354 \\
\hline$\geq 35$ & $25(7.3)$ & $105(9.4)$ & \\
\hline \multicolumn{4}{|l|}{ Skin Color } \\
\hline White & $150(43.8)$ & $483(43.6)$ & 0.9407 \\
\hline Other & $192(56.1)$ & $624(56.3)$ & \\
\hline \multicolumn{4}{|c|}{ Schooling (years) ${ }^{\mathrm{a}}$} \\
\hline$\leq 8$ & $150(44.3)$ & $478(43.8)$ & \\
\hline $09-12$ & $171(50.5)$ & $546(50.0)$ & 0.7804 \\
\hline$\geq 13$ & $17(5.0)$ & $66(6.0)$ & \\
\hline \multicolumn{4}{|l|}{ Parity } \\
\hline Nulliparous & $167(48.8)$ & $438(39.5)$ & \\
\hline 1-2 deliveries & $116(33.9)$ & $431(38.9)$ & 0.0090 \\
\hline$\geq 3$ deliveries & $59(17.2)$ & $238(21.5)$ & \\
\hline \multicolumn{4}{|c|}{ Previous cesarean section ${ }^{\mathrm{b}}$} \\
\hline Yes & $54(15.8)$ & $191(17.2)$ & 0.5414 \\
\hline \multicolumn{4}{|c|}{ Previous preterm birth ${ }^{c}$} \\
\hline Yes & $18(5.2)$ & $69(6.3)$ & 0.4966 \\
\hline
\end{tabular}


Table 1 (Continued)

\begin{tabular}{|c|c|c|c|}
\hline \multirow[t]{2}{*}{ Condition } & Tocolysis & Expectant & \multirow[t]{2}{*}{$p$ Value } \\
\hline & $\mathrm{n}(\%)$ & n (\%) & \\
\hline \multicolumn{4}{|c|}{ Previous preterm labor $^{d}$} \\
\hline Yes & $39(11.4)$ & $113(10.2)$ & 0.5164 \\
\hline \multicolumn{4}{|c|}{ Previous pPROM ${ }^{\mathrm{e}}$} \\
\hline Yes & $23(6.7)$ & $98(8.8)$ & 0.2126 \\
\hline \multicolumn{4}{|c|}{ Previous cerclage $^{f}$} \\
\hline Yes & $9(2.6)$ & $14(1.2)$ & 0.0750 \\
\hline \multicolumn{4}{|l|}{ Prenatal care ${ }^{g}$} \\
\hline Yes & $319(93.8)$ & $1053(95.2)$ & 0.3110 \\
\hline \multicolumn{4}{|l|}{ Use of alcohol $^{\mathrm{h}}$} \\
\hline Yes & $42(12.3)$ & $183(16.6)$ & 0.0556 \\
\hline \multicolumn{4}{|l|}{ Smoking } \\
\hline Yes & $45(13.1)$ & $192(17.3)$ & 0.0673 \\
\hline \multicolumn{4}{|c|}{ Antenatal substance abuse } \\
\hline $\begin{array}{l}\text { Yes or before } \\
\text { pregnancy }\end{array}$ & $19(5.5)$ & $73(6.5)$ & 0.4911 \\
\hline No & $323(94.4)$ & $1034(93.4)$ & \\
\hline \multicolumn{4}{|l|}{ Vulvovaginitis $^{i}$} \\
\hline Yes & $65(32.5)$ & $194(29.6)$ & 0.4376 \\
\hline \multicolumn{4}{|c|}{ Urinary tract infection ${ }^{\mathrm{j}}$} \\
\hline Yes & $86(33.4)$ & $313(36.6)$ & 0.3440 \\
\hline \multicolumn{4}{|c|}{$\begin{array}{l}\text { Vaginal bleeding during } \\
\text { pregnancy }^{k}\end{array}$} \\
\hline Yes & $119(35.0)$ & $282(25.5)$ & 0.0007 \\
\hline \multicolumn{4}{|l|}{ Anemia' } \\
\hline Yes & $96(29.0)$ & $314(29.0)$ & 0.9878 \\
\hline \multicolumn{4}{|c|}{$\begin{array}{l}\text { Cervical insufficiency } \\
\text { (clinical or US) }^{m}\end{array}$} \\
\hline Yes & $12(11.0)$ & $20(4.2)$ & 0.0059 \\
\hline \multicolumn{4}{|l|}{ Cerclage $^{n}$} \\
\hline Yes & $10(3.1)$ & $19(1.9)$ & 0.1708 \\
\hline \multicolumn{4}{|c|}{ Maternal comorbidity } \\
\hline Yes & $79(23.1)$ & $336(30.3)$ & 0.0095 \\
\hline \multicolumn{4}{|c|}{ Membrane integrity ${ }^{\circ}$} \\
\hline Yes & $320(94.9)$ & $853(81.1)$ & $<0.0001$ \\
\hline \multicolumn{4}{|l|}{$\begin{array}{l}\text { Antenatal } \\
\text { corticosteroids }^{p}\end{array}$} \\
\hline Yes & $274(80.8)$ & $138(12.6)$ & $<0.0001$ \\
\hline \multicolumn{4}{|c|}{ Maternal Complication ${ }^{q}$} \\
\hline Yes & $67(19.7)$ & $94(8.6)$ & $<0.0001$ \\
\hline
\end{tabular}

Abbreviations: pPROM, pre-labor premature rupture of membranes; US, ultrasonography;

Note: Missing information for - a: 21; b: 1; c: 14; d: 5; e: 5; f: 3; g: 3; h: 7; i: 594; j: 39; K: 5; I: 38; m: 874; n: 163; o: 61; p: 19; q: 19.
Table 2 Characteristics at admission and perinatal outcomes comparing women who were treated with tocolytic drugs and women who were treated expectantly $(n=1,449)$

\begin{tabular}{|c|c|c|c|}
\hline Variables & $\begin{array}{l}\text { Tocolysis } \\
\text { n (\%) }\end{array}$ & $\begin{array}{l}\text { Expectant } \\
\mathrm{n}(\%)\end{array}$ & $p$ Value \\
\hline \multicolumn{3}{|c|}{ Adequacy of number of prenatal care visits ${ }^{a}$} & $<0.0001$ \\
\hline Adequate $(\geq 6)$ & $101(35.5)$ & $507(52.7)$ & \\
\hline Inadequate $(<6)$ & $183(64.4)$ & $455(47.3)$ & \\
\hline \multicolumn{3}{|c|}{$\begin{array}{l}\text { Number of contractions in 10-minute at } \\
\text { admission }^{\text {b }}\end{array}$} & 0.0006 \\
\hline$<3$ & $132(57.3)$ & $288(44.3)$ & \\
\hline$\geq 3$ & $98(42.6)$ & $362(55.6)$ & \\
\hline \multicolumn{3}{|c|}{$\begin{array}{l}\text { Cervical dilatation } \geq 5 \mathrm{~cm} \text { in the current } \\
\text { hospitalization }{ }^{c}\end{array}$} & $<0.0001$ \\
\hline Yes $(\geq 5)$ & $116(35.6)$ & $606(58.6)$ & \\
\hline \multicolumn{3}{|c|}{$\begin{array}{l}\text { Cervical effacement } \geq 50 \% \text { in the current } \\
\text { hospitalization }^{\mathrm{d}}\end{array}$} & 0.9174 \\
\hline Yes $(\geq 50 \%)$ & $187(87.7)$ & $526(87.5)$ & \\
\hline \multicolumn{3}{|l|}{ Birthweight } & $<0.0001$ \\
\hline$\leq 1,500 \mathrm{~g}$ & $120(35.2)$ & $161(14.6)$ & \\
\hline 1,501 to $2,500 \mathrm{~g}$ & $181(53.2)$ & $535(48.5)$ & \\
\hline$>2,500 \mathrm{~g}$ & $39(11.4)$ & $406(36.8)$ & \\
\hline \multicolumn{3}{|c|}{ Gestational age at birth (weeks) } & $<0.0001$ \\
\hline$<32$ & $151(44.1)$ & $171(15.4)$ & \\
\hline $32-33$ & $82(23.9)$ & $124(11.2)$ & \\
\hline $34-36$ & $109(31.8)$ & $812(73.3)$ & \\
\hline
\end{tabular}

Missing information for: a: 203; b: 569; c: 91; d: 635.

(significantly more contractions, cervical dilation, and effacement) (-Table 4).

On the multiple analysis, cases undergoing tocolysis presented 29 times more risk of receiving corticosteroids, 18 times considering only cases under 34 weeks. The rate of maternal complications was $55 \%$ higher for the cases under 34 weeks, in which labor inhibition was attempted ( - Tables $\mathbf{5}$ and $\mathbf{6}$ ).

\section{Discussion}

Here we present the results of the EMIP for tocolysis in cases of PTB due to PTL. Among the cases that delivered preterm ( $<37$ weeks), we studied and compared the tocolysis and the expectant management groups. The main results show that tocolysis is favored in cases of earlier labor at admission and also among those with less than 34 weeks of gestation, using preferably CCB, with success in achieving increased corticosteroid use, in spite of higher maternal and perinatal complication rates.

The use of antenatal corticosteroids and tocolysis have been previously analyzed in the World Health Organization (WHO) Multicountry Survey on Maternal and Newborn Health, with data from 29 different countries, including 


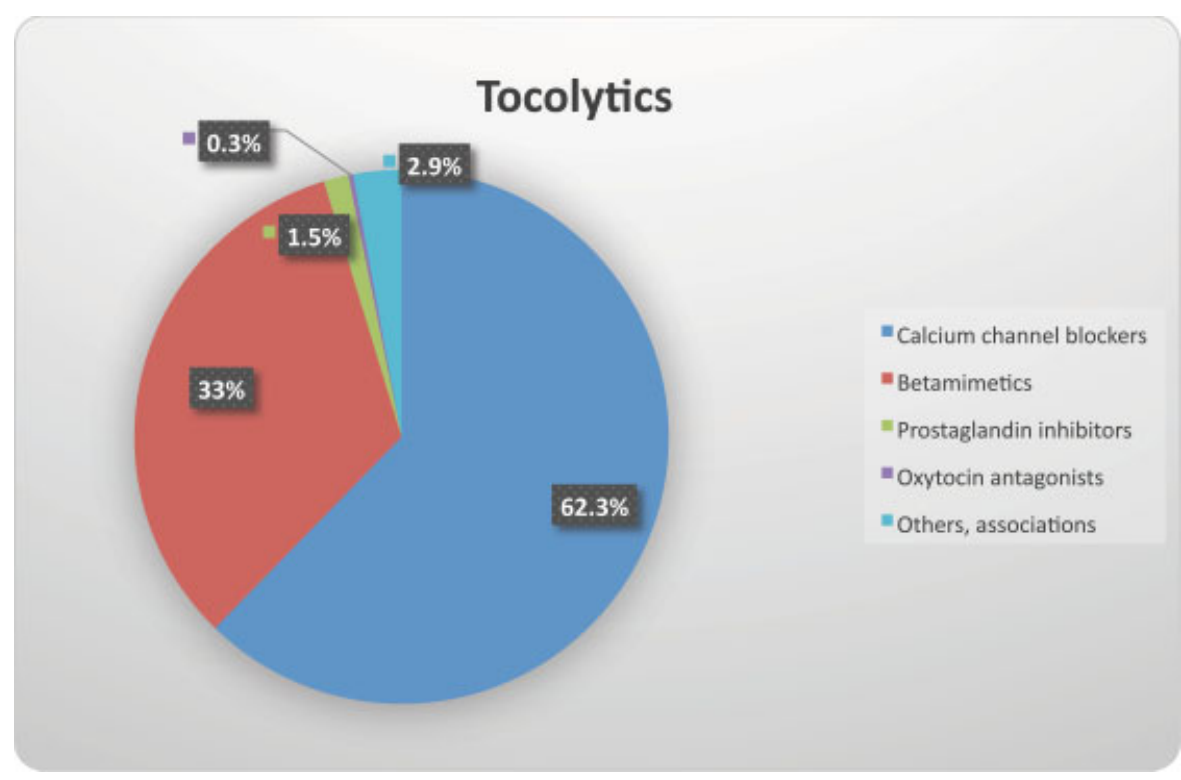

Fig. 2 The proportion of different tocolytic drugs used in the Brazilian Multicenter Study on Preterm Birth (EMIP, in the Portuguese acronym) among spontaneous preterm birth submitted to tocolysis.

Brazil, with overall $6 \%$ of PTB and among women who delivered at 26-34 weeks of gestation, 52\% received antenatal corticosteroids. ${ }^{20}$ In the WHO-multicountry study, the specific data on Brazil presented a low number of subjects (288 women), with $30 \%$ coverage of corticosteroids in the considered gestational age interval and $13 \%$ of tocolysis and antenatal corticosteroids (only 14 women). We do not have a population-based study and need to highlight that most of the 20 considered facilities in our study (EMIP) were tertiary care centers, which might explain the difference in our findings, with overall $12 \%$ of preterm deliveries, $23.6 \%$ of tocolysis among PTB due to PTL and $80 \%$ of combined corticosteroids and tocolysis. In the current study, we only considered PTL; however, the analysis on the providerinitiated PTBs on the same database has also shown over $70 \%$ use of corticosteroids between 28-31weeks of gestation. ${ }^{8}$

Tocolysis is still a very controversial topic; Nonetheless, most clinical protocols consider it plausible to attempt inhibition aiming the complete course of corticosteroids. ${ }^{9}$

Table 3 Acute tocolysis: betamimetics compared with calcium channel blockers $(n=342)$

\begin{tabular}{|c|c|c|c|}
\hline Variables & $\begin{array}{l}\text { Betamimetics } \\
\text { n (\%) }\end{array}$ & $\begin{array}{l}\text { Calcium channel blockers } \\
\text { n (\%) }\end{array}$ & $p$ Value \\
\hline \multicolumn{4}{|l|}{ Categorical Variables* } \\
\hline Therapeutic failure $^{\mathrm{a}}$ & $17(15.4)$ & $21(10.1)$ & 0.1611 \\
\hline Antenatal corticosteroids ${ }^{\mathrm{b}}$ & $85(75.2)$ & $177(83.8)$ & 0.0588 \\
\hline Maternal complications ${ }^{c}$ & $21(18.5)$ & $43(20.3)$ & 0.6989 \\
\hline Neonatal morbidity $^{\mathrm{d}}$ & $86(78.1)$ & $179(86.4)$ & 0.0577 \\
\hline \multicolumn{4}{|l|}{ Delivery Variables $^{\mathbf{e} * *}$} \\
\hline Vaginal & $73(66.9)$ & $161(78.5)$ & \\
\hline Forceps & $1(0.9)$ & $3(1.4)$ & 0.0493 \\
\hline \multirow[t]{2}{*}{ C-section } & $35(32.1)$ & $41(20.0)$ & \\
\hline & (mean SD) & & \\
\hline Duration of use in hours ${ }^{f \text { "'t }}$ & $18.94(20.1)$ & $28.38(28.3)$ & 0.0533 \\
\hline Gestational age at birth in weeks ${ }^{g^{\prime \prime}}$ & $31.25(3.5)$ & $31.17(3.4)$ & 0.7252 \\
\hline Newborn birthweight $(g)^{h^{h \prime}}$ & $1741.0(651.6)$ & $1753.4(661.4)$ & 0.6995 \\
\hline Neonatal intensive care unit (days) & $21.04(24.9)$ & $14.99(20.9)$ & 0.0264 \\
\hline
\end{tabular}

Abbreviation: SD, standard deviation.

Notes: Categorical variables: ${ }^{*}$ Chi square test; ${ }^{* *}$ Fisher exact test; numeric variables; ${ }^{* * *}$ Mann-Whitney test. Missing information for: a- 24; b- 18; c- 18; d- 25; e- 28; f: 40; g: 16; h: 18; i: 45. 
Table 4 Comparison of characteristics at admission and birth outcomes in spontaneous preterm birth $<34$ weeks between women who were treated with tocolytic drugs and women who were treated expectantly (Chi-square test) $(n=528)$

\begin{tabular}{|c|c|c|c|}
\hline Variables & $\begin{array}{l}\text { Tocolysis } \\
\text { n (\%) }\end{array}$ & $\begin{array}{l}\text { Expectant } \\
\mathrm{n}(\%)\end{array}$ & $p$ Value \\
\hline \multicolumn{3}{|c|}{$\begin{array}{l}\text { Vaginal bleeding in the current } \\
\text { hospitalization }^{\mathrm{a}}\end{array}$} & 0.8340 \\
\hline Yes & $51(23.2)$ & $61(24.1)$ & \\
\hline \multicolumn{3}{|c|}{ Contractions in 10 minutes $(<3)^{\mathrm{b}}$} & 0.0106 \\
\hline Yes & $97(62.1)$ & $73(47.7)$ & \\
\hline \multicolumn{3}{|c|}{$\begin{array}{l}\text { Cervical dilatation } \geq 5 \mathrm{~cm} \text { in the current } \\
\text { hospitalization }{ }^{c}\end{array}$} & $<0.0001$ \\
\hline Yes & 87 (39.5) & $203(74.0)$ & \\
\hline \multicolumn{3}{|c|}{$\begin{array}{l}\text { Cervical effacement } \geq 50 \% \text { in the current } \\
\text { hospitalization }^{d}\end{array}$} & 0.0334 \\
\hline Yes & 127 (87.5) & 141 (94.6) & \\
\hline \multicolumn{3}{|c|}{ Birth weight ${ }^{\mathrm{e}}$} & 0.9717 \\
\hline$\leq 1,500 \mathrm{~g}$ & $120(51.7)$ & $147(50.6)$ & \\
\hline $\begin{array}{l}1,501 \text { to } \\
2,500 \mathrm{~g}\end{array}$ & $104(44.8)$ & $133(45.8)$ & \\
\hline$>2,500 \mathrm{~g}$ & $8(3.4)$ & $10(3.4)$ & \\
\hline \multicolumn{3}{|c|}{ Gestational age at birth (weeks) } & 0.1096 \\
\hline$<32$ & $151(64.8)$ & 171 (57.9) & \\
\hline $32-33$ & $82(35.1)$ & $124(42.0)$ & \\
\hline
\end{tabular}

Note: Missing information: a - 56; b - 219; c - 34; d - 234; e - 6 .

The use of antenatal corticosteroids, though, is key in improving the outcomes in preterm babies with $31 \%$ reduction in neonatal deaths and a significant reduction in morbidity as well, including a recently published additional benefit in late preterm with a reduction in the rate of neonatal respiratory complications. ${ }^{11}$ In the current study, it was estimated that women who underwent tocolysis had 29 times more chance of receiving corticosteroids than the ones who did not and the chances were 18 times higher among those under 34 weeks.

In the EMIP, the mean dilation at admission for expectant management was $5.3 \mathrm{~cm}$ and $6.5 \mathrm{~cm}$ under 34 weeks of gestation. Cervical dilation over $5 \mathrm{~cm}$ at diagnosis of PTL has been shown to progress to delivery in less than 24 hours in $50 \%$ of cases, and the chance of delivery before 24 hours increases to $89 \%$ when dilation is over $6 \mathrm{~cm}$ at diagnosis, according to a 2009 study. ${ }^{21}$ Again, we have to emphasize that our study only considered cases that progressed to PTB, which justifies the findings on dilation and effacement at admission.

As pointed previously, it is very difficult to predict PTBs; however, known risk factors and early recognition of the signs and symptoms of PTL should always be considered. ${ }^{3}$ We did find that among the tocolysis group, there were significantly more cases with a history of bleeding during gestation and with cervical insufficiency, which shows that risk factors were assessed.

An important finding in our study was that tocolytic drugs, in general, were related to higher neonatal complication rates. We cannot ascertain causality, and this might be a consequence of the difference in baseline gestational age at admission and not necessarily due to tocolysis. The cases submitted to tocolysis were more preterm (mean gestational age at birth of $\sim 31$ weeks versus 33 weeks in the expectant management group) and therefore more likely to have NICU admission. Unfortunately, we do not have specific data on latency from the time of the initiated use of tocolytic drugs to delivery, but we do have the information on the time of use of medications and, in average, for all considered drugs, it was less than 30 hours ( $\sim 19$ hours for betamimetics and 28 hours for $(\mathrm{CB})$. Given the strong association between tocolysis and corticosteroid use, another factor to be considered for the presented worse neonatal outcomes is the lack of optimal time for corticosteroids action in many cases. The best effect of antenatal corticosteroids is seen after 48 hours of the initiation of treatment. ${ }^{22}$

Tocolytic drugs, in general, were also related to higher maternal complications rates. It is noteworthy that detailed clinical assessment, and an infection screening at admission and during all the in-hospital period is paramount to early diagnose possible infection and other complications. The increase in complications must be addressed in future studies considering all cases of tocolysis and not only those that progressed to PTB.

The most used drug in our study was CCB (mainly Nifedipine), currently considered first-line therapy in many

Table 5 Variables independently associated with tocolysis: multiple analyses by nonconditional logistic regression

\begin{tabular}{|l|l|l|l|l|}
\hline Variables & $\mathbf{n}$ & $p$ Value & OR & Cl 95\% \\
\hline Maternal complications & 1,430 & $<0.0001$ & 2.613 & $1.85-3.67^{\mathrm{a}}$ \\
\hline Neonatal morbidity & 1,380 & $<0.0001$ & 2.742 & $2.01-3.72^{\mathrm{b}}$ \\
\hline Neonatal respiratory distress & 914 & $<0.0001$ & 2.567 & $1.73-3.79^{\mathrm{c}}$ \\
\hline Newborn intubation & 1,386 & $<0.0001$ & 2.372 & $1.77-3.17^{\mathrm{d}}$ \\
\hline Necrotizing enterocolitis & 897 & 0.0022 & 4.024 & $1.64-9.82^{\mathrm{e}}$ \\
\hline Antenatal corticosteroids & 1,430 & $<0.0001$ & 29.105 & $21.05-40.24^{\mathrm{f}}$ \\
\hline
\end{tabular}

Abbreviations: $\mathrm{Cl}$, confidence interval; OR, odds ratio.

Note: Missing information: a - 19; b - 69; c- 535; d - 63; e - 552; f - 19. 
Table 6 Variables independently associated with tocolysis in women who delivered before 34 weeks: multiple analyses by nonconditional logistic regression

\begin{tabular}{|l|l|l|l|l|}
\hline Variables & $\mathbf{n}$ & $\boldsymbol{p}$ Value & OR & Cl 95\% \\
\hline Maternal complications & 517 & 0.0487 & 1.551 & $1.003-2.40^{\mathrm{a}}$ \\
\hline Neonatal morbidity & 482 & 0.3690 & 1.364 & $0.69-2.68^{\mathrm{b}}$ \\
\hline Neonatal respiratory distress & 439 & 0.0753 & 1.810 & $0.94-3.48^{\mathrm{c}}$ \\
\hline Newborn intubation & 483 & 0.1624 & 1.295 & $0.90-1.86^{\mathrm{d}}$ \\
\hline Necrotizing enterocolitis & 424 & 0.1926 & 1.822 & $0.73-4.49^{\mathrm{e}}$ \\
\hline Antenatal corticosteroids & 520 & $<0.0001$ & 18.521 & $11.60-29.55^{\mathrm{f}}$ \\
\hline
\end{tabular}

Abbreviations: $\mathrm{Cl}$, confidence interval; OR, odds ratio.

Note: Missing information: a - 11; b - 46; c - 89; d - 45; e - 104; f - 8 .

countries due to how simple it is to administer, to the low rate of severe side effects and low cost. According to the last Cochrane Systematic review, CCB is better than betamimetics in terms of increased prolongation of pregnancy, decreased maternal side effects and neonatal outcomes. ${ }^{23}$ In our sample, there was a significant difference between these drugs, with increased NICU stay and increased cesarean rates among users of betamimetics. Although known to be less safe than $C C B$, the prescription rate of betamimetics was high, including one third of the sample.

Since many important institutions worldwide have protocols that consider the restricted or no use of tocolysis, the results of this study can also be considered as an alert and incentive to review regional protocols and raise awareness toward the careful use of tocolysis. ${ }^{24-26}$

Brazil is in the tenth position among the countries with the highest absolute number of PTBs, according to the report "Born too soon," published by the World Health Organization in 2013. ${ }^{1}$ Therefore, EMIP was a study with great clinical and epidemiological relevance due to the focus on prematurity and its risk factors and management in the most populated areas of the country. ${ }^{7}$

\section{Conclusion}

The original study was not designed to evaluate the efficiency of tocolysis, and we only have the outcomes of cases that did deliver preterm. However, our findings present a very interesting picture of management on prematurity. The EMIP was an innovative study that enabled a broad and detailed assessment of PTL in Brazil.

Conflicts of Interest

The authors declare that there are no conflicts of interest.

Contributors

Dias T. Z., Fava M. L., Passini Júnior R., Cecatti J. G., Tedesco R. P., Lajos G. J., Rehder P. M., Nomura M. L., Oliveira P. F. and Costa M. L. contributed with the project and interpretation of data, writing of the article, critical review of the intellectual content and final approval of the version to be published.

\section{Acknowledgments}

The authors would like to acknowledge the Brazilian National Research Council (CNPq, in the Portuguese acronym) and the Foundation for Support to Research of the State of São Paulo (Fapesp, in the Portuguese acronym) for financial sponsorship of the study (Fapesp Process 2009/ 53245-5 [Call AP.PPSUS-1]) and state that these organizations did not participate in the study proposal, implementation or interpretation of results. The authors also would like to thank the EMIP study group: Sergio T Marba, Ruth Guinsburg, Francisco E Martinez, Vilma Zotarelli, Lucio T Gurgel, Francisco E Feitosa, George N Chaves, Ana M Porto, Isabela C Coutinho, Antonio C Barbosa Lima, Elias F Melo Jr, Débora F Leite, Melania M Amorim, Adriana SO Melo, Fabiana O Melo, Marília G Martins, Marynea V Nunes, Cláudio S Paiva, Moises D Lima, Djacyr M Freire, Edson G Tristão, Denis J Nascimento,Carlos A Menezes, Marcelo Aquino, Janete Vettorazzi, Cintia E Senger, Augusta MBAssumpção, Marcela AF Guedes, Maria EL Moreira, Vera T Borges, Nelson L Maia Filho, Jacinta P Mathias, Eduardo Souza, Ana CP Zamarian, Silvana M Quintana, Patrícia PS Melli, Fátima A Lotufo, Kaliane Uzilin, Elvira A Zanette, Carla B Andreucci, Tenilson A Oliveira, Laércio R Oliveira, Marcos A N Santos, Nelson Sass, Mirian RF Silveira, Pedro R Coutinho, Luciana Siqueira.

\section{References}

1 Blencowe H, Cousens S, Chou D, et al; Born Too Soon Preterm Birth Action Group. Born too soon: the global epidemiology of 15 million preterm births. Reprod Health 2013;10(Suppl 1):S2. Doi: /1742-4755-10-S1-S2

2 Oliveira RR, Melo EC, Falavina LP, Mathias TA. The growing trend of moderate preterm births: an ecological study in one region of Brazil. PLoS One 2015;10(11):e0141852. Doi: 10.1371/journal. pone.0141852

3 Goldenberg RL, Culhane JF, Iams JD, Romero R. Epidemiology and causes of preterm birth. Lancet 2008;371(9606):75-84. Doi: 10.1016/S0140-6736(08)60074-4

4 Tedesco RP, Passini R Jr, Cecatti JG, Camargo RS, Pacagnella RC, Sousa MH. Estimation of preterm birth rate, associated factors and maternal morbidity from a demographic and health survey in Brazil. Matern Child Health J 2013;17(09):1638-1647. Doi: 10.1007/s10995-012-1177-6 
5 McCormick MC, Litt JS, Smith VC, Zupancic JA. Prematurity: an overview and public health implications. Annu Rev Public Health 2011;32:367-379. Doi: 10.1146/annurev-publhealth-090810182459

6 Liu L, Oza S, Hogan D, et al. Global, regional, and national causes of child mortality in 2000-13, with projections to inform post-2015 priorities: an updated systematic analysis. Lancet 2015;385 (9966):430-440. Doi: 10.1016/S0140-6736(14)61698-6

7 Passini R Jr, Cecatti JG, Lajos GJ, et al; Brazilian Multicentre Study on Preterm Birth study group. Brazilian multicentre study on preterm birth (EMIP): prevalence and factors associated with spontaneous preterm birth. PLoS One 2014;9(10):e109069. Doi: 10.1371/journal.pone.0109069

8 Souza RT, Cecatti JG, Passini R Jr, et al; Brazilian Multicenter Study on Preterm Birth study group. The burden of provider-initiated preterm birth and associated factors: evidence from the Brazilian Multicenter Study on Preterm Birth (EMIP). PLoS One 2016;11 (02):e0148244. Doi: 10.1371/journal.pone.0148244

9 Haas DM, Caldwell DM, Kirkpatrick P, McIntosh JJ, Welton NJ. Tocolytic therapy for preterm delivery: systematic review and network meta-analysis. BMJ 2012;345:e6226. Doi: 10.1136/bmj. e6226

10 NijmanTA, van Vliet EO, Koullali B, Mol BW, Oudijk MA. Antepartum and intrapartum interventions to prevent preterm birth and its sequelae. Semin Fetal Neonatal Med 2016;21(02):121-128. Doi: 10.1016/j.siny.2016.01.004

11 Roberts D, Brown J, Medley N, Dalziel SR. Antenatal corticosteroids for accelerating fetal lung maturation for women at risk of preterm birth. Cochrane Database Syst Rev 2017;3(03): CD004454. Doi: 10.1002/14651858.CD004454.pub3

12 van Vliet EO, Boormans EM, de Lange TS, Mol BW, Oudijk MA. Preterm labor: current pharmacotherapy options for tocolysis. Expert Opin Pharmacother 2014;15(06):787-797. Doi: 10.1517| 14656566.2014.889684

13 Conde-Agudelo A, Romero R, Kusanovic JP. Nifedipine in the management of preterm labor: a systematic review and metaanalysis. Am J Obstet Gynecol 2011;204(02):134.e1-134.e20. Doi: 10.1016/j.ajog.2010.11.038

14 Anotayanonth S, Subhedar NV, Garner P, Neilson JP, Harigopal S. Betamimetics for inhibiting preterm labour. Cochrane Database Syst Rev 2004;(04):CD004352. Doi: 10.1002/14651858.CD004352. pub2
15 Reinebrant HE, Pileggi-Castro C, Romero CL, et al. Cyclo-oxygenase (COX) inhibitors for treating preterm labour. Cochrane Database Syst Rev 2015;(06):CD001992. Doi: 10.1002/14651858.CD001992.pub3

16 Flenady V, Reinebrant HE, Liley HG, Tambimuttu EG, Papatsonis DN. Oxytocin receptor antagonists for inhibiting preterm labour. Cochrane Database Syst Rev 2014;(06):CD004452. Doi: 10.1002/ 14651858.CD004452.pub3

17 Crowther CA, Hiller JE, Doyle LW. Magnesium sulphate for preventing preterm birth in threatened preterm labour. Cochrane Database Syst Rev 2002;(04):CD001060. Doi: 10.1002/14651858. CD001060

18 Vogel JP, Nardin JM, Dowswell T, West HM, Oladapo OT. Combination of tocolytic agents for inhibiting preterm labour. Cochrane Database Syst Rev 2014;7(07):CD006169. Doi: 10.1002/14651858. CD006169.pub2

19 Lajos GJ, Tedesco RP, Passini R Jr, et al; Brazilian Multicenter Study on Preterm Birth Study Group. Methodological issues on planning and running the Brazilian Multicenter Study on Preterm Birth. Sci World J 2015;2015:719104

20 Vogel JP, Souza JP, Gülmezoglu AM, et al; WHO Multi-Country Survey on Maternal and Newborn Health Research Network. Use of antenatal corticosteroids and tocolytic drugs in preterm births in 29 countries: an analysis of the WHO Multicountry Survey on Maternal and Newborn Health. Lancet 2014;384(9957):1869-1877. Doi: 10.1016/S0140-6736(14)60580-8

21 How HY, Khoury JC, Sibai BM. Cervical dilatation on presentation for preterm labor and subsequent preterm birth. Am J Perinatol 2009;26(01):1-6. Doi: 10.1055/s-0028-1090586

22 ACOG Committee on Obstetric Practice. ACOG Committee Opinion No. 475: antenatal corticosteroid therapy for fetal maturation. Obstet Gynecol 2011;117(2 Pt 1):422-424. Doi: 10.1097/ AOG.0b013e31820eee00

23 Flenady V, Wojcieszek AM, Papatsonis DN, et al. Calcium channel blockers for inhibiting preterm labour and birth. Cochrane Database Syst Rev 2014;(06):CD002255. Doi: 10.1002/14651858. CD002255.pub2

24 World Health Organization. WHO recommendations on interventions to improve preterm birth outcomes. Geneva: WHO; 2015

25 National Institute for Health and Care Excellence. Preterm labour and birth. London: NICE; 2015

26 Royal College of Obstetricians \& Gynaecologists. Tocolysis for women in preterm labour. London: RCOG; 2011 